Daria KEISS-DOLAŃSKA

(Gdańsk, UG)

\title{
CEZAREA/WIEŻA STRATONA W WYBRANYCH ŹRÓDLACH PISANYCH
}

Pierwszą wzmiankę o Wieży Stratona można odnaleźć pośród papirusowych dokumentów, tworzących tak zwane Archiwum Zenona. Dokumenty te zostały odkryte przypadkiem w 1915 r., w miejscu hellenistycznej Filadelfii, koło Oazy Fajum ${ }^{1}$. Obecnie dokumenty te są przechowywane w muzeach w Kairze, Stanach Zjednoczonych i Wielkiej Brytanii².

Zenon urodził się w Caunus w Azji Mniejszej ${ }^{3}$. Był z pochodzenia Grekiem, synem Agreofonta ${ }^{4}$. Pełnił funkcję urzędnika przy boku ministra gospodarki Apolloniusza ${ }^{5}$, który to znów był mianowany przez Ptolemeusza II Filadelfosa (285-246 prz. Chr.) ${ }^{6}$. Dokument, w języku greckim, zawierający informację o Wieży Stratona, jest datowany na 259 rok prz. Chrystusem ${ }^{7}$. Zenon towarzyszył Apolloniuszowi w podróży do Egiptu przez Jerozolimę ${ }^{8}$. Dokument wspominający Wieżę Stratona jest przechowywany w Muzeum w Ka-

\footnotetext{
${ }^{1}$ M. Stern, Zeno (Papyri of), Encyclopaedia Judaica (= EJ), vol. XXI, ed. F. Skolnik - M. Berenbaum, Detroit $2007^{2}, 509$.

${ }^{2}$ Por. tamże. Muzeum w Kairze prowadzi stronę internetową gdzie można obejrzeć zdjęcia wraz z opisem przechowywanych tam papirusów, w tym dokumentów z Archiwum Zenona: [http:// ipap.csad.ox.ac.uk/index.shtml] 2011:09:10 (Photographic Archive of Papyri in the Cairo Museum). Także Uniwersytet w Michigan prowadzi stronę dotyczącą Archiwum Zenona: [http://www.lib. umich.edu/reading/Zenon/about.html] 2011:09:11 (University of Michigan Papyrus Collection: The Zenon Papyri).

${ }^{3}$ Por. Stern, Zeno, EJ XXI 509.

${ }^{4}$ Por. tamże; A. Łukaszewicz, Świat papirusów, Warszawa 2001, 170.

${ }^{5}$ Por. Stern, Zeno, EJ XXI 509.

${ }^{6}$ Por. G. Foerster, The early history of Caesarea, ,Bulletin of the American Schools of Oriental Research. Supplementary Studies" 19 (1975) $9=$ The joint expedition to Caesarea Maritima, ed. Ch.T. Fritsch - G. Downey - G. Foerster - H. Hazard - I. Levey, Studies in the history of Caesarea Maritima 1, Missoula 1975; Łukaszewicz, Świat papirusów, s. 170.

${ }^{7}$ Por. M. Avi-Yonah, Caesarea, EJ IV 333; Foerster, The early history of Caesarea, s. 9; R. Stieglitz, Stratonos Pyrgos, Migdal Sar, Sebastos: history and archaeology, w: Caesarea Maritima: a retrospective after two millennia, ed. A. Raban - K. Holum, Documenta et Monumenta Orientis Antiqui 21, Leiden - New York 1996, 593; L. Levine, Caesarea under Roman rule, Studies in Judaism in Late Antiquity 7, Leiden 1975, 7.

${ }^{8}$ Por. Stern, Zeno, EJ XXI 509; Avi-Yonah, Caesarea, EJ IV 333.
} 
irze i jest skatalogowany jako Papyri Cairo Zenon 59.0049. Dowiadujemy się z niego, że Zenon i Apolloniusz zatrzymali się tutaj w celu zakupu żywności,

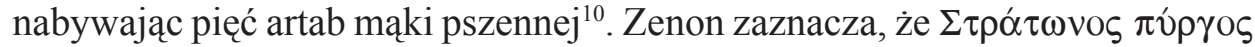
posiadało wówczas dogodny port ${ }^{11}$. Pieter Pestman zauważa, że podróż Antoniusza i Zenona zaczęła się właśnie od Wieży Stratona ${ }^{12}$. Wylicza także, opierając się na datach podanych przez Zenona, że miała ona miejsce parę dni przed 1. lutego 259 roku $^{13}$.

Ciekawe wspomienie o Wieży Stratona pojawia się w papirusowych archiwach starożytnego miasta Oksyrynchos. W 1896 roku Bernard Grenfell i Artur Hunt odnaleźli je prowadząc wykopaliska w Bahr Jusuf (Kanat Józefa ${ }^{14}$. Odkryto tam ponad 10.000 papirusów ${ }^{15}$, które są datowane od początku okresu rzymskiego aż do $\mathrm{X}$ wieku naszej ery ${ }^{16}$. Były one kiedyś częścią miejskiego archiwum, skąd zostały usunięte ${ }^{17}$. Dokument, w którym pojawia się wzmianka o Wieży Stratona, jest datowany na wczesny II wiek ${ }^{18}$, choć Robert Stieglitz zaznacza, że powstał on do II wieku i jest kopią jakiegoś zapisu z wcześniej-

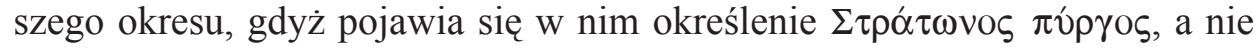

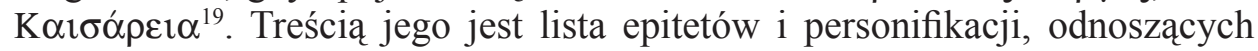
się do bogini Izydy (' $I \sigma ı)$ ) ze wskazaniem, pod jaką personifikacją była ona czczona $\mathrm{w}$ danej krajnie geograficznej ${ }^{20}$. Przejęcie kultu tej egipskiej bogini dowodzi silnego wpływu kultury Egiptu na świat grecko-rzymski ${ }^{21}$. We Wieży Stratona była ona czczona pod dwoma personifikacjami, jako Hellady-Grecji ('E $\lambda \lambda \alpha \dot{\alpha} \delta \alpha)$ oraz Dobroci ('A $\gamma \alpha \theta \eta ́))^{22}$.

\footnotetext{
${ }^{9}$ Por. Stieglitz, Stratonos Pyrgos, Migdal Sar, Sebastos, s. 593.

${ }^{10}$ Por. Foerster, The early history of Caesarea, s. 9. Artaba jest miarą ciał sypkich równą 30-stu litrom, zob. M. Dandamaev - V. Lukonin - P. Kohl, The culture and social institutions of Ancient Iran, Cambridge 2004³, s. 139, przypis 17, oraz s. 145.

${ }^{11}$ Por. Zenon papyri: Catalogue général des antiquites egyptiennes du Musée du Caire, vol. 1, Nr 59.004, ed. C.C. Edgar, Le Caire 1925.

${ }^{12}$ Por. P. Pestman, A guide to the Zenon archive, Papyrologica Lugduno-Batava 21A, Leiden 1981, 264 (Zenon in Palestine in the years 26 and 27 [260-258]. Journey through Judea and Galilea).

${ }^{13}$ Por. tamże, s. 264. Dokument podaje (Papyri Cairo Zenon 59.004: wers 16) datę szóstego dnia miesiąca Audnaios, czyli 6 stycznia; zob. Euzebiusz z Cezarei, Historia Kościelna, thum. A. Lisiecki, POK 3, Poznań 1924, 518 (Skorowidze: Kalendarz Macedoński).

${ }^{14}$ Por. Łukaszewicz, Świat papirusów, s. 129.

${ }^{15}$ Por. tamże.

${ }^{16}$ Por. tamże, s. 131.

${ }^{17}$ Por. tamże.

18 Por. Graeco-Egyptian Literary Papyri 1380, w: The Oxyrhynchus Papyri, vol. XI, ed. B. Grenfell - A. Hunt, London 1915, 190.

${ }^{19}$ Por. Stieglitz, Stratonos Pyrgos, Migdal Sar, Sebastos, s. 593; zob. Graeco-Egyptian Literary

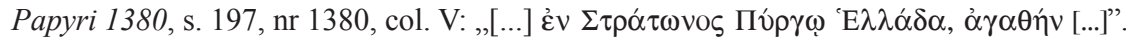

${ }^{20}$ Por. Stieglitz, Stratonos Pyrgos, Migdal Sar, Sebastos, s. 593-594; Graeco-Egyptian Literary Papyri 1380, s. 191-192.

${ }^{21}$ Por. tamże, s. 192.

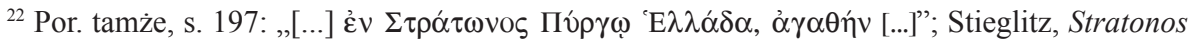


Warto nadmienić, że periegeta Skylaks Karyjczyk (VI/V w. prz. Chr.)

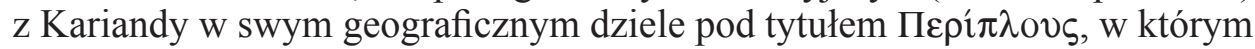
opisuje swoją dwu i pół letnią podróż ${ }^{23}$, gdy wspomina o miastach leżących wzdłuż linii brzegowej Syrii i Fenicji, wymieniając Dorę jako miasto sydońskie, milczy o $\Sigma \tau \rho \alpha ́$ $\tau \omega v o \varsigma ~ \pi u ́ \rho \gamma o \varsigma^{24}$; Skylaks został wysłany przez Dariusza Hystaspisa ok. 510 r. prz. Chr., aby sprawdził, gdzie Indus wpada do morza ${ }^{25}$. Można więc przypuszczać, że Wieża Stratona jeszcze wtedy nie istniała.

Tacyt wspomina Cezareę, jako stolicę prowincji Judei, w której często rezydował cesarz Wespazjan ${ }^{26}$. Opis wyglądu Cezarei w I w. po Chr. można natomiast odnaleźć w dwóch monumentalnych dziełach Józefa Flawiusza: Wojnie Żydowskiej i Dawnych dziejach Izraela. Oba fragmenty zawierające opis Cezarei pochodzą zapewne z okresu, kiedy Flawiusz przebywał w Cezarei jako jeniec wojenny, czyli pomiędzy lipcem 67 a grudniem $69 \mathrm{roku}^{27}$ :

„Uwagę swoją skierował [Herod] również na miasto nadmorskie, które wówczas znajdowało się w opłakanym stanie - nazywało się Zamkiem Stratona lecz dzięki swemu dogodnemu położeniu mogło stać się przedmiotem szczodrobliwej działalności. Zbudował je całkowicie z białego kamienia i ozdobił wspaniałym pałacem [...]. Całe bowiem wybrzeże od Dory do Joppy, między którymi w środku leży to miasto, nie miało żadnego portu [...]. Jednakże król, nakładem znacznych kosztów i swoją ambitną przedsiębiorczością, przezwyciężył żywioł i zbudował port większy niż w Pireusie, a w jego zatokach dalsze głębokie przystanie. Choć miejsce to z natury było nieprzyjazne, Herod usilnym staraniem pokonał przeszkody [...]. Gdy zbudowano część podmorską, postawił nad wodą nabrzeże, które miało dwieście stóp szerokości. Jego część o szerokości stu stóp służyła do łamania fal, stąd jej nazwa „Prokymia” (Falochron) - a pozostała podtrzymywała mur kamienny okalający port. Wystrzelały zeń w odstępach ogromne wieże, z których najwynioślejsza i najwspanialsza otrzymała nazwę od imienia pasierba Cezara - Druzjon. Liczne pomieszczenia sklepione służyły za miejsca zakwaterowania załóg przybijających okrętów, a biegnący przed nimi wokoło mur za szeroką promenadę dla wychodzących na ląd. Wjazd do portu znajdował się w stronie północnej wiatr północny, bowiem jest w tym miejscu najłagodniejszy. Po obu stronach wjazdu stały trzy potężne posaggi wsparte na kolumnach, z których jedne,

\footnotetext{
Pyrgos, Migdal Sar, Sebastos, s. 594.

${ }^{23}$ Por. M. Cary - E. Warmington, Starożytni odkrywcy, tłum. B. Wojciechowski, Warszawa 1968, 144-145.

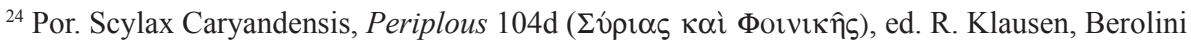
$1831,229$.

${ }^{25}$ Por. Cary - Warmington, Starożytni odkrywcy, s. 144.

${ }^{26}$ Por. Tacitus, Historiae II 79, 1, ed. Loeb, I, London 1962, 162, thum. S. Hammer: Tacyt, Dzieła, I, Warszawa 1957, 112: rozjechali się Mucjanus do Antiochii, Wespazjan do Cezarei: pierwsza Syrii, druga Judei jest stolicą".

${ }^{27}$ Por. M. Hadas-Lebel, Józef Flawiusz. Żyd Rzymski, tłum. J. Radożycki, Warszawa 1997, 91.
} 
znajdujące się po lewej ręce wpływających, podtrzymywała masywna wieża, drugie, po prawej ręce, spoczywały na dwu prostych, połączonych z sobą blokach i górowały nad przeciwległą wieżą. Przylegające do portu domy były także wzniesione z białego kamienia. Do portu biegły ulice miasta, odmierzone w równej odległości od siebie. Na wzgórzu, naprzeciw wjazdu do portu, stał przybytek Cezara, zdumiewający pięknem i rozmiarami. Znajdował się w nim ogromny posąg Cezara, nie ustępujący swemu pierwowzorowi - posagowi Zeusa Olimpijskiego - i drugi Romy, równy posagowi Hery w Argos. Miasto to ofiarował prowincji, port oddał do użytku płynącym tym szlakiem żeglarzom, a Cezara uczcił całym tym zespołem. Dlatego miejscowość tę nazwał Cezarea. Inne budowle: amfiteatr, teatr i place publiczne zostały zbudowane w stylu godnym jej nazwy. Ustanowił także igrzyska urządzane co pięć lat i tak samo nazwał je według imienia Cezara. [...]"28.

Pisząc o zabytkach Cezarei nie sposób pominąć jeszcze ważnego spostrzeżenia, iż Herod Wielki budując Cezareę Nadmorską ${ }^{29}$ urzeczywistnił pomysły wybitnego rzymskiego architekta i inżyniera Marka Witruwiusza Pollio ${ }^{30}$.

${ }^{28}$ Josephus Flavius, Bellum Judaicum I 21, 5-8 (I 408-415), ed. Loeb, London 1956, 192, 194, 196, tłum. J. Radożycki: Józef Flawiusz, Wojna Żydowska, Warszawa 1991, 108-110; por. także Josephus Flavius, Antiquitates Judaicae XV 9, 6 (XV 331-341), ed. B. Niese, III, Berolini 1892, 392, 394, thum. Z. Kubiak - J. Radożycki, Poznań - Warszawa - Lublin 1962, 738-739. We fragmencie zawartym w Dawnych dziejach Izraela odnaleźć można dodatkowo informacje o wieży, która była nazywana Druzjon, od imienia pasierba Cezara, oraz o tym, że Cezarea posiadała podziemne kanały i ścieki.

${ }^{29}$ Cezareę budowano w latach 22-10/9 prz. Chr. Daty te przyjęłam za jedną z hipotez Lee Levine'a. Zauważa on, że inauguracja Cezarei mogła nastąpić również 13/12 r., zamiast 10/9 prz. Chr. Problem tkwi w ustaleniu, od kiedy oficjalnie panował Herod. Uważa on, że władza Heroda została uznana przez Senat Rzymski w 40 r. prz. Chr., ale najczęściej przyjmuje się, że miało to miejsce w roku 37. Paul Lawrence również podaje, że Herod objął urząd w 40 r. prz. Chr. Gideon Foerster podaje obie możliwe daty inauguracji Cezarei: 13/12 oraz 10/9 r. prz. Chr. Michael AviYonah utrzymuje stanowisko, że uroczysta inauguracja nastąpiła w 13 r. prz. Chr. Aleksander Krawczuk podaje datę 9 marca $10 \mathrm{r}$. prz. Chr., zaś początek prac budowlanych wyznacza na r. 24, a nie na rok 22 prz. Chr., jak to czyni Lee Levine oraz Barbara Burell. Walter Otto w RE zaznacza, że Herod I panował oficjalnie od jesieni 40 r. prz. Chr., a Cezareę wraz z portem, Świątynią Augusta i Romy rozpoczął budować w roku 22 prz. Chr., zaś oficjalną inaugurację wraz z igrzyskami wyznacza na marzec 9 r. prz. Chr., por. Levine, Caesarea under Roman rule, s. 11, 149-150, przypis 52; Avi-Yonah, Caesarea, EJ IV 333; Foerster, The early history of Caesarea, s. 11; A. Krawczuk, Herod - Król Judei, Warszawa 1985, 209-210; P. Lawrence, Herod Wielki, w: Atlas historii biblijnej, Warszawa 2009, 130. B. Burell, Herod's Caesarea on Sebastos: urban structures and influences, w: D. Jacobson - N. Kokkinos, Herod and Augustus, „Studies in Judaica” 6 (2009) 217; W. Otto, Herodes nr 14, REAuppl II, Stuttgart 1913, 1-158; B. Levick, Greece and Asia Minor from 43 B.C. to 69 A.D. oraz D. Kennedy, Syria, oraz M. Goodman, Judea, w: The Cambridge Ancient History - second edition, vol. 10, ed. by A. Lintott - A. Bowman - E. Champlin, United Kingdom 20065 , ss. 652-654, 719, 725, 727, 749, 754; Broshi, The archeology of Palestine 63 B.C. to 70 C.E., s. 1-37 oraz D. Bahat, The Herodian Temple, w: The Cambridge history of Judaism, vol. 3: The early Roman period, ed. D. Davies - J. Sturdy - W. Horbury, Cambridge 1999, 38-58.

${ }^{30}$ Por. Ch. Brandon, Cements, concrete, and settling barges at Sebastos: comparisons with 
Decyzja Heroda była bardzo przemyślana, gdyż Witruwiusz dedykował swe dzieło Augustowi ${ }^{31}$, a Cezarea miała być pomnikiem ku jego $\mathrm{czci}^{32}$. Chciał dzięki temu bardziej okazać swoją przychylność wobec Oktawiana. Witruwiusz podkreśla we wprowadzeniu do I księgi, że Oktawian dbał nie tylko o bezpieczeństwo i ustrój państwa, lecz także o estetyczny wygląd budowli publicznych, tak w samym Rzymie, jak i w prowincjach, aby dzięki nim ukazać majestat Imperium Romanum ${ }^{33}$.

W Historii Naturalnej Pliniusza Starszego (23-79) można odnaleźć informację, że Stratonis Turris nazywana jest także Cezareą, którą to pobudował Herod, a Wespazjan podniósł do godności kolonii, jako Prima Flavia ${ }^{34}$.

Euzebiusz z Cezarei był naocznym świadkiem prześladowań chrześcijan w Cezarei Palestyńskiej; najbardziej dotkliwe miały miejsce za panowania cesarza Diolecjana w latach 303-31135. Właśnie im poświęcił swe dwa dzie-

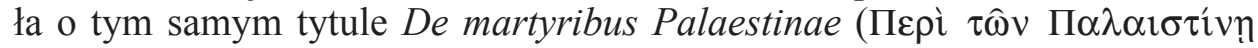

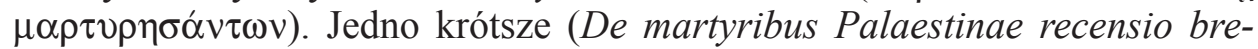
vior) było dodatkiem do zakończenia VIII księgi Historii Kościelnej ${ }^{36}$, drugie zaś samodzielnym opracowaniem (De martyribus Palaestinae recensio prolixior). Krótsze zachowało się $\mathrm{w}$ całości, $\mathrm{z}$ dłuższego posiadamy pojedyncze fragmenty ${ }^{37}$. Oba dzieła powstały zanim Euzebiusz objął biskupstwo (ok. $315)^{38}$. A oto najbardziej realistyczny, a zarazem wstrząsający obraz Cezarei z 13 listopada 308 roku $^{39}$ :

other Roman harbor examples and the descriptions of Vitruvius, w: Caesarea Maritima: a retrospective after two millennia, s. 25-40; H.F. Mallgrave, Architectural theory, vol. 1: An Anthology from Vitruvius to 1870, part IA: Classicism and the Renaissance. The classical and medieval traditions, Oxford 2006, 3-14.

${ }^{31}$ Por. Vitruvius, De architectura I praef. 1, ed. V. Rose, Lipsiae 1899, 1: „...Imperator Caesar [...] de his rebus ea ediderem".

${ }^{32}$ Por. Introduction, w: Caesarea Maritima: a retrospective after two millennia, $\mathrm{s}$. XXVII.

${ }^{33}$ Por. Vitruvius, De architectura I praef. 2, ed. V. Rose, s. 1, thum. K. Kumaniecki: Witruwiusz, O architekturze ksiag dziesięć, wyd. 2, Biblioteka Antyczna, Warszawa 2004, 23.

${ }^{34}$ Por. Plinius Secundus Maior, Historia naturalis V 17, 75, ed. Loeb, II, London 1961, 278 : „Stratonis turris, eadem Caesarea, ab Herode rege condita, nunc colonia Prima Flavia a Vespasiano imperatore deducta".

${ }^{35}$ Por. Levine, Caesarea under Roman rule, s. 131.

${ }^{36}$ Por. A. Lisiecki, Wstęp, POK 3, Poznań 1924, s. XII; Eusebius Caesariensis, Historia Ecclesiastica VIII 4-13; De martyribus Palestinae, ed. G. Bardy, SCh 55, 120-174, thum. A. Lisiecki, POK 3, Poznań 1924, 364-380, 463-495.

${ }^{37}$ Por. Zachowane fragmenty większej recenzji pisma Euzebiusza z Cezarei $O$ męczennikach palestyńskich w przekładzie A. Lisieckiego zob. POK 3, 496-512.

${ }^{38}$ Por. De martyribus Palaestinae recensio prolixior powstało w 311 r., De martyribus Palaestinae recensio brevior powstało na przełomie 313/314 r.; zob. A. Carriker, Eusebius' use of sources, w: tegoż, The library of Eusebius of Caesarea, Leiden - Boston 2003, 38. Paul Carriker zaznacza (s. 39), że Euzebiusz został wybrany biskupem Cezarei w 315 roku.

${ }^{39}$ Por. A. Lisiecki, POK 3, 481, przypis 3. 
„Trybun oddziału wojska imieniem Maksys [...] prawdziwy okrutnik [...] rozebrał błogosławioną Ennatas ze wszystkich szat, tak że tylko od bioder do nóg była okryta [...] oprowadzał ją po całym mieście Cezarei ( $\tau \grave{\eta} v \tau \varepsilon \pi \hat{\alpha} \sigma \alpha \nu$

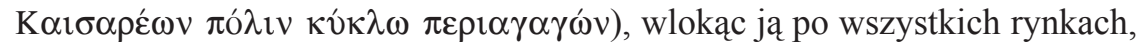
kazał ją smagać rzemieniami [...]. Otóż rozporządził też, by w nocy i we dnie straże pilnowały zwłok, porzuconych pod gołym niebem na pastwę dzikich zwierząt. Można było istotnie widzieć przez długi szereg dni niemałą liczbę mężczyzn, którzy stanęli do usług tego zwierzęcego i barbarzyńskiego rozkazu. Z daleka tedy, jak gdyby chodziło o rzecz wielkiej wagi, dawali baczenie, by ciał nie wykradziono. Dzikie zaś zwierzęta, psy i ptactwo drapieżne na wszystkie strony ludzkie rozrzucały członki. Całe miasto było dookoła zasiane wnętrznościami i kośćmi ludzkimi, tak że nawet tym, co się dawniej z nienawiścią do nas odnosili, nigdy się nic nie wydawało więcej okrutne i groźne, i nie tyle biadali nad nieszczęściem tych, których to spotkało, ile nad sponiewieraniem swej własnej, wszystkim ludziom wspólnej natury. U samych bowiem bram miasta można było oglądać widowisko, przewyższające wszelki opis i wszelkie tragiczne przedstawienie. Nie w jednym tylko miejscu zwierzęta pożerały ludzkie mięso, jakieś kawały wnętrzności widzieli podobno ludzie także wewnątrz bram miejskich" ${ }^{\prime 40}$.

Klementyny, zwane również Pseudoklementynami, będące zbiorem homilii, z których przetrwało dwadzieścia, a których autorstwo przypisuje się papieżowi Klemensowi Rzymskiemu (92-101) $)^{41}$, co jednak jest bardzo wątpliwe, gdyż przypuszcza się, że powstały one w III wieku ${ }^{42}$, także wspominają Cezareę: w Homilii pierwszej pojawia się wzmianka o Klemensie, że gdy odbywał podróż

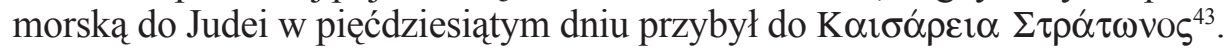

$\mathrm{W}$ innym dziele pod zachowanym tytułem Totius orbis descriptio, które ocalało pod postacią późniejszego tłumaczenia łacińskiego, przedstawiony jest także obraz Cezarei z ok. 350/353 roku. Przetrwały dwie wersje tego thumaczenia: oznaczone symbolem $A$ jest autorstwa Filozofa Młodszego (Junior Philosophus) ${ }^{44}$, drugie z symbolem $B$ - Franciszka Jureta (Franciscus Juretus), zwane także Juretianum ${ }^{45}$. Pierwsze z nich tak opisuje Cezareę:

\footnotetext{
${ }^{40}$ De martyribus Palestinae 9, 7-11, SCh 55, 150-151, POK 3, 482-483.

${ }^{41}$ Por. Stownik pisarzy antycznych, red. A. Świderkówna, Warszawa 2001, 148 (Clementinae [Klementyny, Pseudoklementyny]).

${ }^{42}$ Por. tmże.

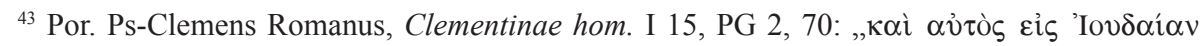

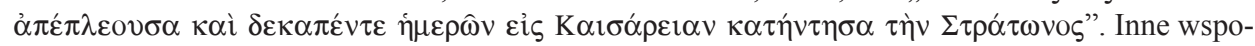
mnienia Klemensa związane z Cezareą, odnaleźć można także w kolejnych homiliach Klementyn: hom. I 20, IV 1, VI 26, XII 5, XIII 7, PG 2, 74, 215, 306, 334, 458.

${ }^{44}$ Por. Junior Philosophus, Totius orbis descriptio, w: Geographi Graeci Minores, vol. 2, ed. C. Müller, Parisiis 1861 (repr. Hildesheim 1965), 513.

${ }^{45}$ Por. tamże.
} 
„Similiter et Caesarea civitas deliciossisima, cuius tetrapylum nominatur ubique, quod unum et novum spectaculum praebet ${ }^{46}[\ldots]$. Sarepta vero, Caesarea, Neapolis et Lydda purpuram praestant ${ }^{47}$.

Drugie zaś następująco:

„Iam etiam Caesarea civitas est similiter deliciosior et abundans omnibus, et dispositione civitatis in multa eminens. Tetrapylon enim ejus nominatur ubique, quod unum et novum aliquod spectaculum praebet ${ }^{48}[\ldots]$. Quae linteamen omni orbi terrarum emittunt et sunt eminentes in omni abundantia. Similiter autem et Sarepta et Caesarea et Neapolis, quomodo et Lydda, purpuram, altithinam ${ }^{49}$.

Według obu przekazów Cezarea była miastem o wysokich zabudowaniach, opływającym we wszelkie dostatki, w którym, tak jak w Sarepcie i Lyddzie, produkowano tkaniny purpurowe, sprzedawane na cały świat; była miastem, które można porównać do najdroższego klejnotu. Interesujący element stanowi tu wzmianka o budowli zwanej tetrapylum, którą nazywa się także tetrapylon, arcus quadrifrons, ianus quadrifrons, tukiem czwórbramnym. Ta budowla w Cezarei, miała być jedyna w swoim rodzaju i znana wszystkim ówcześnie żyjącym. Warto zwrócić uwagę, że Józef Flawiusz, choć pisze o wielu zabudowaniach w Cezarei, nic o niej nie wspomina, więc prawdopodobnie powstała już po jego śmierci ${ }^{50}$.

Kolejnym źródłem wspominającym tę budowlę w Cezarei jest Midrasz Miszle, z której można się dowiedzieć, że gdy odprowadzano zwłoki Rabbiego Akivy, kondukt pogrzebowy po całonocnym marszu doszedł do tetrapylonu, koło którego znajdowały się komory grzebalne ${ }^{51}$. Rabi Akiva ben Josif został stracony podczas prześladowań za cesarza Hadriana w 135 roku $^{52}$.

Z kolei Eutropiusz, historyk rzymski z IV wieku po Chr., w swym zarysie historii Breviarium ab Urbe condita ${ }^{53}$, ukazuje Cezaree jako „obecnie bardzo sławne miasto w Palestynie" "54; określenie to dowodzi świetności i roli, jaką pełniła ona w tym wieku.

${ }^{46}$ Por. Junior Philosophus, Totius orbis descriptio A 23 (26), Geographi Graeci Minores, vol. 2, 517-518.

${ }^{47}$ Por. tamże A 31 (30), s. 518-519.

${ }^{48}$ Por. tamże B 23 (26), s. 517-518.

${ }^{49}$ Por. tamże B 31 (30), s. 518-519.

${ }^{50}$ Por. aparat krytyczny wraz z przypisami w: Geographi Graeci Minores, vol. 2, s. 517-518, $\S 26:$ tetrapylum.

${ }^{51}$ Por. Levine, Caesarea under Roman rule, s. 44, 179, przypis 117; Midrash Mishle IX 17-20, ed. S. Buber, Vilno 1893, 31b.

${ }^{52}$ Por. Polski Słownik Judaistyczny, red. Z. Borzymińska - R. Żebrowski, t. 1, Warszawa 2003, 61-62, 358; H. Freedman - S. Wald, Akiva (50-135 C.E.), EJ I 562-563.

${ }^{53}$ Por. Stownik pisarzy antycznych, s. 206 (Eutropius).

${ }^{54}$ Por. Eutropius, Breviarium ab Urbe condita VII 10, 3, ed. H. Droysen - P. Landolfique, 
Podobnie Prokopiusz z Gazy (ok. 465-568) ${ }^{55}$ w swoim panegiryku ku czci

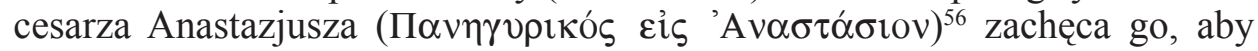
odnowił już podupadający port w Cezarei. Zaznacza, że z okresu świetności tego portu pozostała już tylko jego nazwa, dedykowana Oktawianowi Augustowi. Falochrony portowe, według opisu Prokopiusza, były już tak zniszczone, że nawet, gdy okręt uniknął rozbicia na morzu wskutek gwałtownej burzy i szczęśliwie zakotwiczył w porcie Cezarei, to jednak miotany w nim falami, roztrzaskiwał się. Dodaje też, że jeśli Anastazjusz nie odbuduje portu, zginie coś, co można było nazwać „dziełem”57. Słowa Prokopiusza można uznać za przytyk skierowany do cesarza Anastazjusza, gdyż wiadomo, że w V wieku okręty cumowały i wypływały z Cezarei: sam Prokopiusz żeglował z Cezarei na Rodos, a następnie do Konstantynopola ${ }^{58}$.

Prawie współczesny Prokopiuszowi periegeta Hierokles, w swoim przewodniku pod tytułem $\Sigma v v \eta ́ \kappa \delta \eta \mu ం \varsigma)$ przeznaczonym dla podróżujących po wschodnich prowincjach Imperium Romanum ${ }^{59}$, wymienia Cezareę, jako

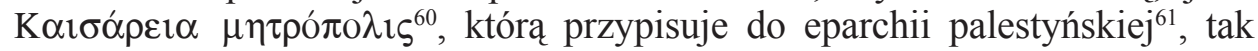
samo jak Dorę ${ }^{62}$. Przewodnik ten, datowany na początek VI w., zawiera listę 64 rzymskich eparchii leżących na Wschodzie oraz omawia 935 innych miast ${ }^{63}$.

Podobnie współczesny im Stephanos z Bizancjum, erudyta grecki z VI w. ${ }^{64}$, autor olbrzymiego 60-księgowego leksykonu geograficznego pt. Ethnica ${ }^{65}$,

MGHaa II, Berolini 1879, 120: „[...] quas Caesareas nominarent, sicut in Mauretania a rege Iuba et in Palaestina, quae nunc urbs est clarissima".

${ }^{55}$ Por. Stownik pisarzy antycznych, s. 425 (Prokopios).

${ }_{56}$ Por. Procopius Gazaeus, Panegyricus in imperatorem Anastasium, ed. I. Bekkerus B.G. Niebuhrius, Corpus Scriptorum Historiae Byzantinae (= CSHB), XII/1, Bonnae 1829, 489516, lub ed. C. Kempen, Bonn 1918, 1-17.

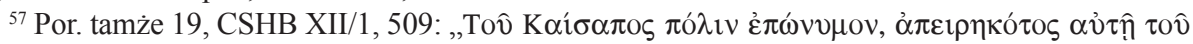

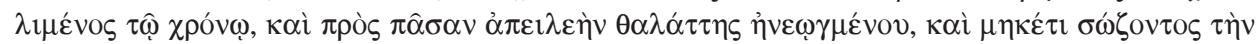

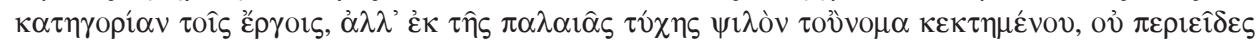

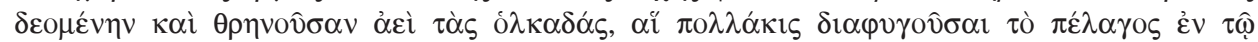

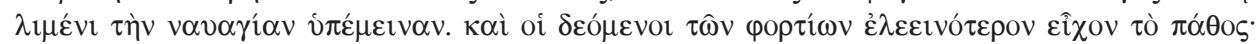

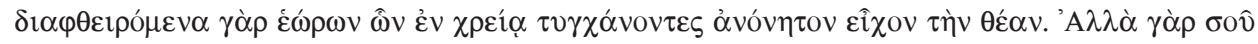

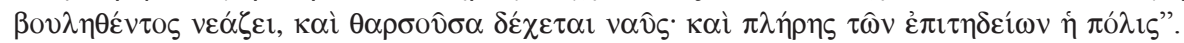

${ }^{58}$ Por. Levine, Caesarea under Roman rule, s. 137, 240, przypis 12.

${ }^{59}$ Por. Dictionary of Greek and Roman biography and mythology, ed. W. Smith, II, London 1846, 453 (Hierocles $\mathrm{nr}$ 6).

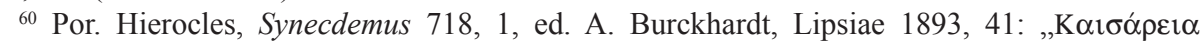
$\mu \eta \tau \rho{ }^{\prime} \pi \mathrm{o} \lambda \iota \varsigma^{\prime \prime}$.

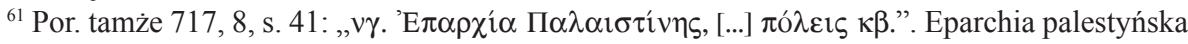

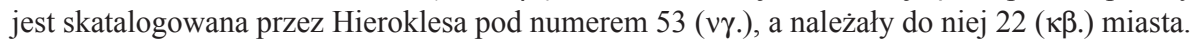

${ }^{62}$ Por. tamże 718, 2, s. 41: „, $\hat{\omega} \rho \alpha ”$.

${ }^{63}$ Por. Dictionary of Greek and Roman biography and mythology, vol. 2, s. 453.

${ }^{64}$ Por. Stownik pisarzy antycznych, s. 474 (Stephanos).

${ }^{65}$ Por. Stephanus Byzantinus, Ethnica, ed. A. Meinekius, Berolini 1849 (repr. Graz 1958), 1-713. 


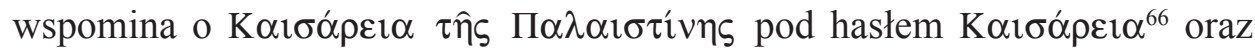
umiejscawia koło niej miasto Dorę, określając ją jako mniejsze miasteczko ${ }^{67}$.

Natomiast Prokopiusz z Cezarei, urodzony prawdopodobnie w 507 r., miał studiować prawo w tak zwanym cezareńskim kolegium prawników w Cezarei ${ }^{68}$. Kolegium to znane było, jako Caesarienses advocati lub Caesariensis advocatio oraz Palaestina advocatio ${ }^{69}$. Termin advocatio jest tutaj użyty, jako synonim słowa collegium. Szkoła w Cezarei miała większe znaczenie od tej w Berytos (dzisiejszy Bejrut), i jest często wspominana w zbiorze praw Justyniana ${ }^{70}$.

W 2. poł. VI wieku Jan Malalas napisał Kronikę świata (Chronographia), która choć uważana jest za dzieło nieudolne kompozycyjnie i nacechowane brakiem krytycyzmu ${ }^{71}$, zawiera cenne informacje dotyczące również Cezarei Palestyńskiej. Posiada ona m.in. informację, że Wespazjan zbudował w niej teatr i odeon w miejscu zburzonej synagogi, a budowę tych obiektów ufundował z łupów wojennych zagrabionych Żydom ${ }^{72}$.

Powstała w VII w. Kronika Wielkanocna (Chronicon Paschale, Chronicon Alexandrinum, Chronicon Constantinopolitanum, napisana przez anonimowego autora należącego do otoczenia patriarchy Sergiusza (610-638) ${ }^{73}$, zawiera datę fundacji Cezarei przez Heroda wyznaczając ją na 742 ab Urbe condi$t a^{74,}$ a według greckiego systemu olimpiad, na pierwszy rok 192 Olimpiady.

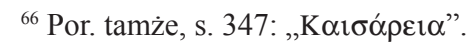

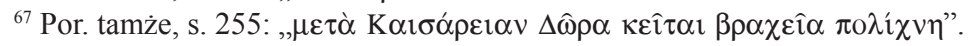

${ }^{68}$ Por. Levine, Caesarea under Roman rule, s. 59-60.

${ }^{69}$ Por. Advocatio nr 4, Contributions to Latin lexicography, ed. H. Netteleship, New York 2010
} (first published 1889), 51 (Advocatio nr 4); A. Konarek, Wstęp, w: Prokopiusz z Cezarei, Historia sekretna, tłum. tenże, Warszawa 1998, 6. To ostatnie określenie wynika stąd, że Caesarea była ówcześnie stolicą prowincji Palaestina Prima, czyli Palaestinae Primae Metropolis, zob. Iustinianus, Institutiones II 8, § 2 (Quibus alienare licet vel non), ed. E. Schrader - T. Tafel - G. Clossius C. Maier, w: Corpus Iuris Civilis, vol. 1, Berolini 1832, 273. Informacja ta znajduje się w przypisach do powyższego fragmentu pod hasłem ad Caesarienses advocatos.

${ }^{70}$ Por. Iustinianus, Institutiones II 8, § 2 (Quibus alienare licet vel non); III 19 (20), § 12 (De inutilibus stipulationibus), s. 273 i 517; Iustinianus, Digesta, ed. T. Mommsen, w: Iustinianus, Institutiones. Digesta, ed. P. Krueger - T. Mommsen, w: Corpus Iuris Civilis, vol. 1, Berolini 1889, s. XVI (Omnem rei publicae nostrae sanctionem iam esse purgatam). Warto zauważyć, że w edycji E. Schradera pojawia się forma przymiotnika Caesarienses, zaś w edycji P. Kruegera i T. Mommsena: Caesareenses.

${ }^{71}$ Por. Mała encyklopedia kultury antycznej A-Z, Warszawa 1990, 443-444 (Malalas Jan).

${ }^{72}$ Por. Joannes Malalas, Chronographia X 5 111, ed. L. Dindorfius, CSHB XIX, Bonn 1831,

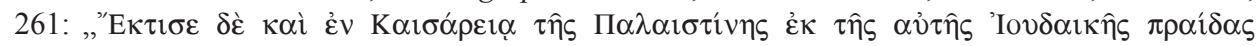

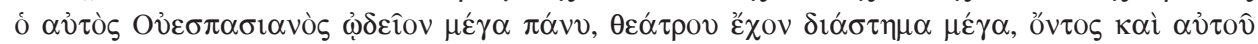

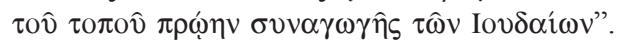

${ }^{73}$ Por. O. Jurewicz, Historia literatury bizantyjskiej. Zarys, Wrocław 1984, 113.

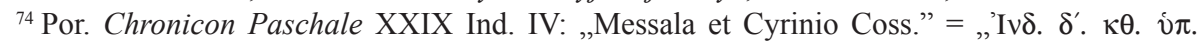

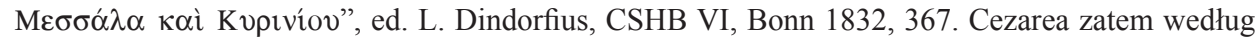
Kroniki Wielkanocnej, powstała 742 lata po założeniu Rzymu, czyli 742 lata po roku 753. Przyjmując, że rok 753 będzie liczony, jako pierwszy, otrzymamy 12 r. (prz. Chr.). Biorąc zaś pod uwagę rok, 
Przypisywane Euzebiuszowi Tablice chronologiczne (Chronicon) podają datę założenia Cezarei różną od powyższej o jeden rok, wyznaczając ją na $741 \mathrm{r}$. ab Urbe condita, a po 2005 latach od narodzin Mojżesza; zgadza się zaś chronologia, według systemu olimpiad, czyli w pierwszym roku 192 Olimpiady $^{75}$.

Wreszcie prawie dwa wieki później chronograf Jerzy Synkellos w swej kronice Chronographia, powstałej ok. 800 r. po Chr. ${ }^{76}$, wspomina o dokonanej

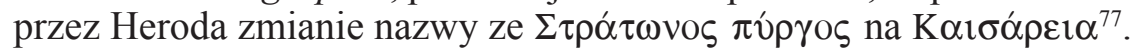

Na podstawie powyższych uwag źródłowych można zauważyć, jak ważną rolę pełniła w świecie starożytnym Wieża Stratona, zwana później Cezareą: była miejscem nie tylko odpoczynku dla żeglarzy i garnizonem dla rzymskich żołnierzy, ale również miejscem, gdzie odbywały się krwawe prześladowania chrześcijan. Posiadała największy sztuczny port w obszarze basenu Morza Śródziemnego ${ }^{78}$, pozostawiając w historii niezatarty ślad swojego istnienia i świetności.

\section{CAESAREA/STRATON'S TOWER IN THE SELECTED GREEK AND LATIN SOURCES}

(Summary)

In my paper I have tried to present briefly a history of Caesarea in Palestine, relying on the Greek and Latin sources. Originally, the city was called Straton's Tower, but it became famous in the Roman Empire as Caesarea. I have described briefly how did Caesarea change from a small village to the capital of province Palestina Prima Metropolis. Among the authors who were used as the sources

w którym sprawowali swe rządy konsulowie: Marek Waleriusz Messala Barbatus Appianus i Publiusz Sulpicius Quirinius, których przyporządkowuje Kronika Wielkanocna, jako sprawujących urząd w roku 742 ab Urbe condita, potwierdza się wyznaczony rok, por. Dictionary of Greek and Roman biography and mythology, vol. 3, ed. W. Smith, London 1849, 1398 (Parallel Tabels); Mata encyklopedia kultury antycznej A-Z, s. 650. R. Hanslik, M. Valerius Messala Barbatus Appianus nr 260, w: RE XV, Stuttgart 1955, 126.

${ }^{75}$ Por. Eusebius, Chronicorum libri duo, ed. A. Schoene, vol. 2, Berolini 1866, 142. Różnica pomiędzy Kronikq Wielkanocna, a Tablicami chronologicznymi, wynika z tego, iż Kronika Wielkanocna za pierwszy rok istnienia Rzymu przyjmuje 753 (prz. Chr.), a Tablice chronologiczne rok 752. Cezarea zatem według Tablic chronologicznych, powstała w 741 r. po założeniu Rzymu, czyli 741 lat po roku 753 (prz. Chr.), a w pierwszym roku 192 Olimpiady. Tak licząc otrzyma się również 12 r. prz. Chr., zob. Dictionary of Greek and Roman biography and mythology, vol. 3, s. 1398 (Parallel Tabels).

${ }^{76}$ Por. Mała encyklopedia kultury antycznej A-Z, s. 715 (Synkellos Gregorios nr 3).

${ }^{77}$ Por. Georgius Syncellus, Chronographia 314c, ed. G. Dindorfius, CSHB XXXII/1, Bonn

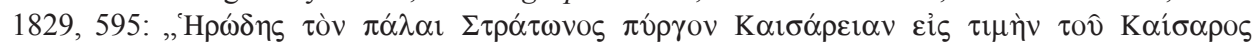

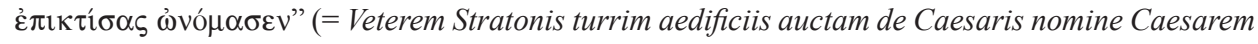
Herodes apellavit).

${ }^{78}$ Por. P. Lawrence, Atlas historii biblijnej, tłum. E. Czerwińska, Warszawa 2009, 130. 
are Flavius Josephus, Georgios Synkellos, Eusebius of Caesarea, Procopius of Caesarea, Procopius of Gaza and Johannes Malalas. 
